\title{
When Does FDI Have Positive Spillovers? Evidence from 17 Transition Market Economies
}

\author{
Yuriy Gorodnichenko \\ UC Berkeley
}

\author{
Jan Svejnar \\ Columbia University
}

April 10, 2014
Katherine Terrell

\begin{abstract}
We use rich firm-level data and national input-output tables from 17 countries over the 2002-2005 period to test new and existing hypotheses about the impact of foreign direct investment (FDI) on the efficiency of domestic firms in the host country (i.e., spillovers). We document that backward linkages have a consistently positive effect on productivity of domestic firms while horizontal and forward linkages show no consistent effect. We also examine how the strength of spillovers varies by sector, FDI source, institutional environment (corruption, red tape, level of development), firm's distance to the technological frontier, and other firm- and country-specific characteristics.
\end{abstract}

JEL: F23, M16, O16, P23

Keywords: FDI, spillovers, institutions, transition economies, efficiency,

Acknowledgements: We would like to thank the following individuals for their useful comments on earlier drafts of the paper: Simeon Djankov, Anne Harrison, Beata Javorcik, Josef Konings, Kamal Saggi, Walter Steingress, and seminar participants of the World Bank Workshop on Productivity, ACES sessions at the ASSA Meetings; Annual Conference of the Austrian National Bank, International Economics Seminar at the University of Michigan, International Business Seminar at George Washington University; Conference of the Higher Economics School in Moscow, and FDI Conference at Ghent University. Tomislav Ladika provided excellent research assistance. We are grateful to the European Bank for Reconstruction and Development for making this research possible through funding and data availability. Gorodnichenko also thanks NSF and the Sloan Foundation, while both Gorodnichenko and Svejnar thank the Grant Agency of the Czech Republic (Grant No. P402/10/2130), for financial support. We would like to dedicate the paper to Katherine Terrell who passed away while the authors were completing the paper. 


\section{Introduction}

It is widely accepted that firms in many developing countries were weakened by the import-substitution strategies of the 1960s and 1970s. The question that has arisen since then is whether domestic firms have become stronger with the opening up of most economies to foreign investment. More specifically, has the efficiency of domestic firms in transition and emerging market economies improved with the growing presence of foreign direct investment (FDI) within their borders and the opening of these economies to trade? While there is substantial evidence that foreign-owned firms are more efficient than domestic firms,${ }^{1}$ the evidence on FDI spillovers remains relatively mixed.

In this paper we use the rich 2002 and 2005 Business Environment and Enterprise Performance Surveys (BEEPS) of firms in 17 transition economies, together with industrylevel input-output data, to advance our knowledge of when, where and under what conditions FDI has efficiency spillovers on domestic firms. First, while most of the literature has focused on horizontal spillovers, we examine both vertical and horizontal spillovers. In this context, we advance the literature by being able to analyze forward and backward linkages of multinational enterprises (foreign firms) with a direct firm-specific variable and compare this with the results using the usual indirect industry-specific variable based on input-output tables. By using firm- rather than just industry-level linkage variables we are able to eliminate bias introduced by using aggregate data, reduce measurement error, and exploit firm-level variation in linkage variables that is much greater than the industry-level variation commonly used in the literature. Perhaps more importantly, by comparing the strength of linkages using firm- and industry-level variables we can assess if the spillover is confined to a domestic firm actually supplying a foreign firm or spread over many domestic firms in a given industry, thus making FDI a measure of generally available technology. We also include in the analysis of vertical spillovers the

\footnotetext{
${ }^{1}$ See e.g., the seminal work of Caves (1974) and the more recent work of Djankov and Hoekman (2000), Haskell, Pereira and Slaughter (2007), and Sabirianova, Svejnar and Terrell (2005, 2012).
} 
concept of selling to or buying from firms outside of the country, i.e., importing and exporting, since vertical spillovers need not be constrained to linkages with foreign firms within the host country alone.

Second, we use a broader measure of efficiency than many other studies by analyzing how efficiently firms generate sales revenue, taking into account inputs of capital, labor and materials. This is equivalent to total factor productivity but broader in that it also captures improvements in pricing, marketing and other aspects of revenue generation that are crucial for success of firms in the transition and emerging market economies that are trying to catch up with their competitors from advanced countries.

Third, we test a number of existing and several new hypotheses. For example, we are among the first to shed light on the impact of a country's institutions (corruption and bureaucratic red tape) and level of development on the strength of vertical and horizontal spillovers. We also use our data set to address older (but as yet not conclusively answered) questions in the literature, such as whether spillovers depend on a firm's 'absorptive capacity."

Fourth, we are able to provide much larger comparative evidence on more heterogeneous firms than has been possible to date. ${ }^{2}$ Our analysis covers firms in both the service and manufacturing sectors, while existing studies focus on manufacturing. This is important because much of the recent FDI is in services. We are also able to estimate the effects separately for small firms, while most existing evidence is for medium and large firms. Being able to cover smaller firms is important because smaller firms tend to be the new entrepreneurs and engines of growth in many transition and emerging market economies. Finally, we also test for differences in spillovers among new and old firms - in our case firms that existed prior to 1990 (before the fall of the communist regime) and those that started afterwards.

\footnotetext{
${ }^{2}$ Our analysis includes firm level data from Albania, Bulgaria, Croatia, Czech Republic, Estonia, Georgia, Hungary, Kazakhstan, Latvia, Lithuania, Poland, Romania, Russia, Serbia, Slovakia, Slovenia, and Ukraine.
} 
We find positive backward spillovers for the domestically owned firms (i.e., selling to foreign-owned firms, whether in the country or outside, raises a domestic firm's efficiency). On the other hand, our estimates suggest that buying inputs from or competing with foreign firms confers positive spillovers only in older firms and firms in the service sector. We test for the impact of the institutional environment on spillovers and do not find a strong effect. Similarly, our tests for the effect of the technological quality of FDI, proxied by whether FDI originates in advanced or developing countries, indicate that there is no systematic difference in efficiency spillovers from "higher" v. "lower" quality FDI. Finally, there is limited statistical support for the argument that the absorptive capacity of firms affects the degree of spillovers in that the distance of a domestic firm from the efficiency frontier dampens horizontal spillovers in manufacturing and backward spillovers among old firms.

The paper is organized as follows. In Section 2 we present a brief overview of the literature, while in Section 3 we describe our data and analytical methodology. We present our baseline findings on spillovers in Section 4, our analysis of the institutions and quality of FDI in Section 5, and the results related to the absorptive capacity in Section 6. We conclude in Section 7.

\section{Efficiency Spillovers from FDI}

Foreign firms may have efficiency and other "spillover" effects on local competitors (horizontal spillovers) as well as on upstream and downstream domestic firms (vertical spillovers). The spillover (broadly defined as a transfer of managerial practices, production methods, marketing techniques or any other knowledge embodied in a product or service) may occur through a number of channels. Local firms may for instance learn to imitate a new process or improve the quality of their products or marketing through observation or through interaction with foreign managers in business chambers and from former employees of foreign firms. Local firms may also benefit from the entry of new 
professional services or suppliers as a result of the foreign firm entry. Foreign firms may act as catalysts for domestic suppliers to improve quality or time efficiency by demanding higher standards. On the other hand, foreign firms may have a negative effect on domestic firms' output and efficiency if they "steal" their market or best human capital. If domestic firms cut back production in the face of foreign competition, they may experience a higher average cost as fixed costs are spread over a smaller scale of production (Aitken and Harrison, 1999). Similarly, if the best employees leave for foreign firms, efficiency declines.

Most studies examine "horizontal spillovers" and do so within a production function framework. ${ }^{3}$ The effect of foreign presence on the productivity of domestic firms in a given industry is captured by the coefficient on the share of foreign firms' output or employment in that industry. The evidence from this research is mixed. Most studies of developing countries suggest that the horizontal spillover effect is nil or negative (e.g., studies of Morocco by Haddad and Harrison, 1993; Venezuela by Aitken and Harrison, 1999; Bulgaria and Romania by Konings, 2001; the Czech Republic by Kosova, 2010; China by Abraham, Konings and Slootmaekers, 2006; and a large cross-section of countries by Fons-Rosen et al., 2013). ${ }^{4}$ On the other hand, several studies find positive horizontal spillovers in the more developed economies such as the UK (e.g., Haskel et al., 2007) and the US (e.g., Keller and Yeaple, 2009). Hence, this puzzle is of some interest in the literature and in policy.

While studies of horizontal spillovers are numerous, until recently there were few empirical studies on vertical spillovers. This is surprising given the early analysis by Lall (1980) of the positive backward linkage effects of foreign firms on the Indian trucking industry. Moreover, vertical spillovers are more likely to be positive than horizontal

\footnotetext{
${ }^{3}$ The literature on FDI spillovers has been burgeoning in recent years. We do not attempt to summarize the large and rapidly growing literature, but simply highlight the work that has motivated the analysis in this paper. We refer the interested reader to a survey by Gorg and Greenaway (2003) and more recent papers.

${ }^{4}$ In the Chinese case, Abraham, Konings and Slootmaekers (2006) find positive horizontal spillovers for certain types of firms.
} 
spillovers since foreign firms have an incentive to improve the productivity of their suppliers rather than that of their competitors. ${ }^{5}$ The empirical papers that have appeared recently do indeed find evidence that is consistent with the view of technology transfer through backward linkages in the manufacturing sectors of, for example, Hungary (Schoors and van der Tol, 2001), Indonesia (Blalock and Gertler, 2005), Lithuania (Javorcik, 2004), the Czech Republic (Stancik, 2007) and the United Kingdom (Girma, Gorg and Pisu, 2008). However, these studies rely only on a variable that is constructed from input-output tables at the industry level, rather than a direct firm-specific measure. ${ }^{6}$

Various factors have been considered to condition the effect of spillovers. For example, a popular hypothesis is that negative horizontal spillovers in developing countries are due to the low "absorptive capacity" of domestic firms. It is argued that the larger the technology and human capital gap between the domestic and foreign firms, the less likely the domestic firms are able to exploit the potential of spillovers. ${ }^{7}$ The implication is that positive spillovers should be found in more technologically advanced firms, sectors or countries. There is some evidence supporting the human capital gap hypothesis (e.g., Borensztein, De Gregorio and Lee, 1998, using country level data, and Blalock and Gertler, 2002, using firm level data), but the evidence with respect to the technology gap is mixed. For example, with U.K. plant-level data, Girma, Greenaway and Wakelin (2001) find that local firms that are "technologically comparable" to foreign firms enjoy greater spillover, whereas Haskel, Pereira and Slaughter (2007), using the same micro data conclude that plants further away from the technology frontier gain most from foreign presence in their sector (thus supporting Findlay, 1978). Abraham et al. (2006) find no relationship between

\footnotetext{
${ }^{5}$ Blalock and Gertler (2005) point out that foreign firms may establish a relationship with multiple suppliers to reduce dependency on a single supplier and that this will then benefit all firms that purchase these vendors' output. Consistent with this view, Lin and Saggi (2007) show theoretically how exclusivity in the contractual relationship between a multinational and its local supplier reduces the competition among local suppliers and can lower backward linkages and local welfare relative to autarky.

${ }^{6}$ Gorodnichenko, Svejnar and Terrell (2010) focus on firm-level measures of linkages and find that vertical linkages stimulate domestic firms to innovate.

${ }^{7}$ The first paper with this argument is perhaps Cohen and Levinthal (1989). The reverse hypothesis - that spillovers increase with a larger technology gap - was put forth earlier by Findlay (1978).
} 
the gap and spillovers in China. The findings may differ because of different measures in that some studies use labor productivity and others total factor productivity. They may also differ because of the methodology used. As Girma (2005) points out, it may be necessary to take into account certain threshold values. He presents evidence that the productivity benefit from FDI increases with absorptive capacity until some threshold level beyond which it becomes less pronounced. ${ }^{8}$ The findings may also differ because other factors are not being taken into account. In their study of China, Abraham et al. (2006) find that if they control for structure of ownership, there is a significant effect. Finally, studies that proxy technology by the level of R\&D consistently find positive horizontal spillovers in the R\&D sector (see e.g. Kinoshita, 2000, using data from the Czech Republic).

Sabirianova, Svejnar and Terrell (2005) use 1992-2000 firm-level data on the population of industrial firms in the Czech Republic and Russia and find that the productivity gap between domestic and foreign firms is increasing in industries with a greater foreign presence. However, in the Czech Republic this negative horizontal spillover effect is diminished and eventually reversed over time, whereas in Russia it becomes stronger and is associated with domestic firms falling further behind the technology frontier. Since the Czech Republic has been more open to FDI and trade, and has adopted a stronger (European Union) rule of law than Russia, Sabirianova et al. (2005) argue that the different pattern in these two countries suggests that spillovers are more likely to be positive in environments characterized by competition, rule of law and openness to foreign investment and international trade.

The business environment may affect spillovers through a number of channels. Competition may for instance strengthen domestic firms and their ability to absorb spillovers. Thus Moran, Graham and Blomstrom (2005) argue that local firms that sell to

\footnotetext{
${ }^{8}$ We note that the notion of threshold value is also in Borensztein, De Gregorio and Lee (1998) who however argue differently - that a minimum threshold of human capital is needed before a firm can absorb FDI spillovers.
} 
foreign affiliates in protected markets are often subscale in size and inefficient in operation. Several studies also find supporting evidence on the positive impact of competition. For example, Blalock and Gertler (2008) and Abraham et al. (2006) show that spillovers are positive only in sectors with more competition in Indonesia and China, respectively. However, the relationship between horizontal spillovers and competition may not be uniform. For example, Sembenelli and Siotis (2002) find, using Spanish data, that only firms in the R\&D sector enjoy positive spillovers when there is more competition. Aghion, Burgess, Redding, and Zilibotti (2005) develop a model showing that firm responses to liberalization are likely to be heterogeneous, with technologically more advanced firms being more likely to respond by investing in new technologies and production processes, and find supporting evidence with Indian data. Hence, an open and competitive environment may yield different spillover effects depending on where the domestic firm is relative to the technological frontier.

The institutional environment may also affect the quality of FDI brought into a country and hence spillovers. Foreign affiliates in better institutional environments are likely to bring with them better technology as they are more able to maximize profits and hence have more to spill. Or, as Moran, Graham and Blomstrom (2005, p. 372) put it: "Foreign investors in countries with domestic content, joint venture and technology sharing requirements deploy production technique lagging far behind the frontier in international industry."

The institutional environment can also affect the structure of ownership, which has been found to be correlated with the quality of FDI. Javorcik and Saggi (2011) for instance argue that foreign affiliates that have a higher level of technology tend to be wholly owned, rather than joint-ventures, in order to protect their proprietary asset. A joint-venture arrangement may increase the risk for undesired leakages of the foreign technology as the domestic partner may use the inside information in the production of other goods for which it does not cooperate with the foreign firms. In an environment with inadequate protection 
of intellectual property rights, foreign firms may tend to create wholly-owned affiliates so as to shelter their technological innovations from being copied. Hence, if these hypotheses are correct, one will see larger positive spillovers from wholly-owned foreign firms than from partially-owned foreign firms and the largest spillovers from wholly-owned ones in better institutional environments.

\section{Data and Methodology}

We use data from the Business Environment and Enterprise Performance Survey (BEEPS), a joint initiative of the European Bank for Reconstruction and Development (EBRD) and the World Bank. The survey was first undertaken in 1999-2000, when it was administered to approximately 4,000 enterprises in Central and Eastern Europe (CEE), Turkey and the Commonwealth of Independent States (CIS) to assess the environment for private enterprise and business development. The second and third rounds of the BEEPS were carried out in 2002 and 2005 on approximately 6,500 and 7,900 enterprises, respectively, in the same 27 CIS and CEE countries (including Turkey). In 2005, the BEEPS instrument was administered to approximately the same 27 countries covered by the second round of the BEEPS. The questionnaires and sampling frames of the 2002 and 2005 BEEPS are very similar.

In this paper we use primarily the 2005 BEEPS survey as it contains data on the variables of interest. In those cases when we cannot construct rates of change from the 2005 BEEPS, we construct them by combining information from the 2002 and 2005 BEEPS data sets. The original 2005 data base contains a total of 7,942 firms, with 200-600 firms per country. The share of firms in services ranges from $50 \%$ to $65 \%$ across the 27 countries. Between two-thirds and three-quarters of the firms have less than 50 employees. Approximately $10 \%$ of the firms are foreign owned and another $10 \%$ are state owned. The 
share of firms that export more than $20 \%$ of their output varies widely across countries: from $5 \%$ in Kazakhstan to $30 \%$ in Slovenia.

In addition to the BEEPS data, we rely on data from input-output tables to construct the industry-wide spillover variables. Since we are only able to obtain recent input-output tables for 17 of these economies, we use the BEEPS data for these countries. We have attempted to impute values for countries with missing input-output tables by using the average values from the two closest neighboring countries but we have found that such imputation introduced too much noise in the data. ${ }^{9}$

To assess the extent and nature of spillovers, we focus on revenue efficiency - i.e., how efficiently firms generate sales revenue from inputs of capital, labor and materials. By using sales revenues as the dependent variable, we capture total factor productivity as well as improvements in pricing, marketing and other aspects of revenue generation that are crucial for corporate performance. Our approach explicitly allows for the efficiency of different firms to vary on account of any of these factors. Given the dynamic nature of globalization, we do not presume that firms are in a technical or economic steady state but rather that they are trying to improve their performance by adopting new methods of production, importing advanced technologies, launching new products, learning new managerial and marketing techniques, and implementing other changes. The extent to which firms are able to succeed may of course depend on the institutional environment, an issue that we explore.

We estimate the following baseline regression with pooled data for all 17 countries: ${ }^{10}$

$$
\begin{gathered}
\Delta \ln Y_{i j}=\alpha_{1} \text { Forward }_{j}+\alpha_{2} \Delta \text { Backward }_{j}+\alpha_{3} \text { BHorizontal }_{j}+\alpha_{4} \text { SalesFF }_{i} \\
+\alpha_{5} \text { Import }_{i}+\alpha_{7} C_{i}+\beta^{K} \Delta \ln K_{i}+\beta^{L} \Delta \ln L_{i}+\beta^{M} \Delta \ln M_{i}+X_{i j} \gamma+\epsilon_{i j}
\end{gathered}
$$

\footnotetext{
${ }^{9}$ Information on the country, year and source of our input-output tables is available upon request.

10 Equation (1) can also be interpreted as a first order approximation for more complicated revenue (production) functions.
} 
where $\Delta$ refers to change from 2002 to $2005, i$ and $j$ index firms and industries (at the twodigit NACE level), respectively, and $\ln Y$ is the $\log$ of sales revenues. The three industryspecific spillover variables are: Forward and Backward, for forward and backward linkages, respectively, and Horizontal, for foreign presence in the same industry (described below). The firm-specific spillover variables, which are measured in 2005 levels, include: SalesFF - the share of a firm's sales to foreign firms, ${ }^{11}$ Exports - share of sales exported, and Imports - the share of inputs imported. We include a vector of variables, $C$, to control for competition: a dummy, equal to 1 if the firm indicates it competes in the national market, 0 otherwise; and three dummy variables for low, medium and high elasticity of demand, respectively (with completely inelastic demand serving as the base). ${ }^{12}$ The inputs include: $K$, capital stock (at replacement value and utilization adjusted); $L$, labor (number of employees) and $M$, intermediate material input (including electricity). $X$ is a set of country and two digit NACE industry dummy variables. The industry dummies are interacted with the inputs in order allow for industry-specific production functions.

Foreign presence in industry $j$ (horizontal linkage) is constructed as is typical in the literature:

$$
F P_{j} \equiv \text { Horizontal }_{j} \equiv \frac{\sum_{i} Y_{i} \times s_{i} \times \mathbf{1}(i \in \text { industry } j)}{\sum_{i} Y_{i} \times \mathbf{1}(i \in \text { industry } j)}
$$

where $s_{i}$ is the share of foreign ownership in firm $i$. In our econometric specifications, we exclude own output of the firm in computing Horizontal. Since the number of firms per industry is in some cases small, the estimate of the foreign presence may be sensitive to inclusion of very large firms of either domestic or foreign ownership. To attenuate this problem, we censor the size of sales at the median plus/minus three times the inter-quantile range for a given industry and country. Finally, we note that the variable is constructed

\footnotetext{
${ }^{11}$ A firm is defined as foreign if it has $50 \%$ or more foreign ownership.

${ }^{12}$ The three levels of the elasticity of demand were computed from answers to the question "If you were to raise the price of your good or service by $10 \%$ what response would you get?" The respondent had to select among the following answers: Our customers would continue to buy from us: a) in the same quantities as now (completely inelastic); b) at slightly lower quantities (low); c) at much lower quantities (medium); versus d) many of our customers would buy from our competitors instead (high).
} 
with the share of foreign ownership, rather than with a dummy variable capturing whether the foreign firm is foreign owned or not. However, the share of foreign ownership is typically over $90 \%$.

The vertical linkage variables can be interpreted as follows: Forward $_{j}$ is the average share of domestic firms' inputs in industry $j$ purchased from foreign firms in industry $h$; Backward $_{j}$ is the average share of domestic firms' sales in industry $j$ supplied to foreign firms in industry $h$. To avoid confusion, we note that the concept of forward and backward linkages is derived from the perspective of the foreign firm. Specifically, foreign owned firms provide backward spillovers to domestic firms when they buy from them and forward spillovers when they sell to them. $s_{j h}$ is the share of sales of industry $j$ sold to industry $h$. The shares, taken from the latest input-output table available for each country, are only for domestic intermediate consumption of goods. They exclude "own" purchases or sales from industry $j .{ }^{13}$ The forward and backward linkages are computed as follows:

$$
\begin{aligned}
& \text { Forward }_{j}=\left(\sum_{h \neq j} F P_{h} \times s_{h j}\right) / \sum_{h \neq j} s_{h j}, \\
& \text { Backward }_{j}=\left(\sum_{h \neq j} F P_{h} \times s_{j h}\right) / \sum_{h \neq j} s_{j h},
\end{aligned}
$$

where $F P$ is foreign presence (equivalently Horizontal linkage).

We use firm-level data in the 2005 BEEPS to estimate equation (1) since the 2005 survey provides information on the growth from 2002 to 2005 in sales, exports, and each of the inputs. We use firm level data from both the 2002 and 2005 BEEPS to construct industry level data on changes over time in the three industry level linkage variables, Backward $_{j}$, Forward $_{j}$ and Horizontal $j_{j}$. However, the 2005 BEEPS does not collect information on the 2002-2005 changes in two firm level linkage variables - SalesFF and Imports - hence, these variables are included as their levels in 2005. For symmetry we do the same for Exports.

\footnotetext{
${ }^{13}$ In this approach we differ from some other studies, e.g., Blalock and Gertler's (2002), whose linkage variable includes purchases from its own sector.
} 
The fact that 2002-2005 changes are being regressed on 2005 levels (shares) of the firm-level linkage variables may lead to biased estimates due to endogeneity of firmspecific variables. We may find significant effects of firm-specific variables because of selection (e.g., foreign firms may choose to buy from productive domestic firms) and timing (e.g., output growth between 2002 and 2005 may be high because a firm happened to find a new market or customer in 2005).

There are several points to be made with respect to this potential problem. First, the potential reverse causality does not distort estimates of other key coefficients in the sense that estimating the regression without these variables does not materially change the coefficients or standard errors on the other variables of interest (Backward, Forward, and Horizontal $)$. Hence, even if our estimates of coefficients on firm-specific variables were to suffer from endogeneity, our inference based on other variables is largely unaffected. Second, our linkage variables are shares rather than levels of exports, imports and sales to foreign firms. Because there is no strong a priori reason to expect correlation between productivity and composition of sales, large biases due to reverse causality are not likely. Third, within a subsample of about 800 firms for which we can create a panel with the 2002 and 2005 survey data, the correlation coefficients between the 2002 and 2005 values of Exports, Imports and SalesFF, respectively, are relatively high $-0.95,0.93$ and 0.42 . These coefficients show considerable persistence; especially when one considers that the variables are expressed as shares. Hence, using the 2005 rather than 2002 values should not greatly bias the results because of different timing of the firm specific variables. Furthermore, because export status and other linkage variables typically involve sizable fixed costs, they depend on the level of productivity rather than on its dynamics. Since we control for firm-specific fixed effects by first-differencing the revenue function, we expect possible biases due to selection effects to be small. Finally, we have estimated our baseline regression (1) on the smaller panel subsample using 2002 instead of 2005 values of Exports, Imports and SalesFF. The advantage of this specification is that the timing of the 
values of the firm-specific variables, combined with the other controls (including the firm fixed effects), practically precludes the aforementioned endogeneity problems. It is reassuring that while the coefficients are less significant because of the much smaller sample size and volatile firm level data, the point estimates are similar to those for the full sample. In sum, we recognize the potential problem in the BEEPs survey design and note that in the present case the actual problem is likely to be limited.

There are two additional econometric issues that need to be addressed. One is the potential selection issue of FDI. Foreign firms may for example choose to locate in a given country because it has better telecommunications or other infrastructure which is also improving the efficiency of domestic firms. Foreign firms may also select to enter a given industry because of opportunities that the econometricians do not observe but which improve the efficiency of firms in that industry. We control for this potential selection problem by first-differencing and also adding fixed effects for country and industry to the first-difference specification. First-differencing removes fixed firm-, industry- and country-specific variation such as that brought about by differences in infrastructure. The industry and time dummy variables entered in the first-difference specification control for unobservables that may be driving changes in the attractiveness of a given country or industry.

Finally, there is the potential endogeneity of inputs. It may be argued that the inputs are chosen by the firm based on its productivity and not taking this into account may bias the estimated coefficients. In order to check if this is a serious problem, we estimate a specification that uses the Solow residual as the measure of efficiency:

$$
\begin{gathered}
\Delta \text { Solow }_{i j}=\alpha_{1} \text { Forward }_{j}+\alpha_{2} \Delta \text { Backward }_{j}+\alpha_{3} \Delta \text { Horizontal }_{j}+\alpha_{4} \text { SalesMNE }_{i} \\
+\alpha_{5} \text { Import }_{i}+\alpha_{7} C_{i}+X_{i j} \gamma+\epsilon_{i j}
\end{gathered}
$$

where Solow $_{i j}=\ln Y_{i j}-\beta_{j}^{K} \ln K_{i j}-\beta_{j}^{L} \ln L_{i j}-\beta_{j}^{M} \ln M_{i j}$, with $\beta$ 's being cost shares that we allow to vary by industry and country in the estimation. This approach differs from the specification in equation (1) in that it controls for the endogeneity of inputs by placing 
them on the left hand side of the equation. Naturally, the tradeoff is that to the extent that the assumptions of competition, constant-returns to scale in the revenue function and costminimization are not met, the cost shares may not reflect the equalization of marginal cost and marginal revenue by the firms and the use of cost shares may bias our results.

Given the large sample size of about 4,600 domestic firms with no FDI, we are able to estimate equations (1) and (5) separately for firms in the manufacturing and service sectors, firms with fewer than 30 employees (small) and more than 30 employees (large), firms in existence before these economies went into transition in 1990 (old) and firms created since 1990 (new). This enables us to avoid aggregation bias and answer questions that were not analyzed in previous studies.

The change in the industry level linkage variables (Backward, Forward, and Horizontal) is negative over this period, indicating that the share of output produced by foreign firms was falling, or put differently, that output of domestic firms was growing more rapidly than that of foreign firms. The share of sales to foreign firms rose by $5.7 \%$ on average over the three-year period, and the growth was faster in large than small firms, and in manufacturing than in services. The degree of bribing and the share of managers' time spent with bureaucrats fell over the period by $1 \%$ and $4 \%$ respectively, however the levels remained relatively high with an average of $2.3 \%$ of sales spent on bribing and $5.2 \%$ of managers' time spent with bureaucrats.

\section{Vertical and Horizontal Spillovers and other Baseline Findings}

The key results from estimating equations (1) and (5) are presented in Tables 1 and 2, respectively. The findings for efficiency in both the Cobb-Douglas and Solow residual estimations are very similar in terms of signs, with the former occasionally achieving somewhat higher statistical significance. Given the similarity of results and the fact that 
the Solow residual is a noisy measure of productivity, we continue with the widely used Cobb-Douglas specification (1).

Backward spillover: The coefficient estimates based on the industry level inputoutput table data are similar in magnitude in the two specifications and overall they point to a large positive spillover from supplying to foreign firms. The overall estimates based on all firms, reported in columns 1 of Tables 1 and 2, indicate that a one percentage increase in sales of domestic firms in a given industry $j$ to foreign firms in a given industry $h$ raises the rate of growth of efficiency of domestic firms in industry $j$ by $0.07-0.08 \%$. When estimated by firm categories, the coefficient is positive and statistically significant for large firms $(0.14-$ 0.16) in both models and in the Cobb-Douglas specification also for new firms (0.095) and firms in manufacturing (0.09). The coefficients for other categories of firms are positive but the standard errors are too large to generate statistical significance at conventional test levels.

Forward Spillover: The estimated coefficients are positive but statistically insignificant. The exceptions are firms in the service sector and old firms in the Solow residual equation, which generate significant positive effects. On the whole, our estimates in Tables 1 and 2 suggest that purchasing from industries with a higher share of foreign firms) does not provide major efficiency enhancing effects for domestic firms.

Horizontal Spillovers: The coefficients on this variable are smaller than those on the Forward and Backward variables. They are generally positive, but statistically significant only for old enterprises and to a lesser extent for service sector firms. These findings therefore suggest that firms that compete effectively and benefit from the presence of foreign competitors are those that are well established (old) or operate in a sector where methods and skills of production are relatively visible and transferable (services). The estimated coefficients on old firms and services indicate that a one percent increase in the share of foreign firms' output in a given industry raises the rate of growth of efficiency of old firms in the same industry by $0.06-0.07 \%$ and that of service sector firms by about $0.05 \%$. 
Sales to foreign firms: This firm-specific effect is positive for all categories of firms and the point estimate is similar for each firm type across the two specifications. All the estimated coefficients are statistically significant in the Cobb-Douglas specification and all but two are significant in the Solow model. A one percent increase in sales to foreign firms as a share of a firm's output in 2005 is associated with a $0.05 \%$ increase in the growth of efficiency in both the Cobb-Douglas and Solow specifications, irrespective of firm-type. Thus, supplying foreign firms has a direct effect on the productivity, in addition to the indirect effects measured by the industry-level variables.

Exports: The coefficients on share of sales exported are positive and robust, with very similar point estimates for all firm-types across both specifications. A one percent increase in the share of sales that are exported is associated with a $0.06-0.07 \%$ increase in the rate of growth of efficiency of local firms, with a potentially higher effect on old and service sector firms. The only estimate that is not statistically significant is the effect for large firms in the Cobb-Douglas specification.

Imports: The effects of importing are not significant for any of the firm categories in either specification. This lack of significance parallels that with respect to purchases from foreign firms (forward linkage) above.

Firms that compete in national markets have on average $0.02 \%$ faster efficiency growth than firms that compete only in local markets. According to both specifications, the effect is statistically significant, irrespective of firm age, in small firms and firms in services. We interpret this as indicating that firms that compete in the national markets tend to be larger and able to take advantage of economies of scale as well as market power for networking and lobbying. Perhaps they are also able to practice transfer pricing/accounting and shift production from one region to another according to demand.

Elasticity of Demand: Firms that report low, medium and high elasticities of demand, compared to the base of completely inelastic demand, have slower growth of the efficiency of generating revenue from inputs. The negative point estimate is larger for firms reporting 
medium and high elasticities than those reporting a low value. Since the dependent variable is sales revenues rather than physical output, the results suggest that firms with inelastic demand (no competition) can increase prices faster than those facing higher demand elasticity and that either a) the expected positive effect of competition on efficiency is outweighed by a monopoly power pricing effect or $b$ ) the Schumpeterian view that monopoly power gives firms more resources to innovate and become more efficient holds.

To sum up, the estimates in Tables 1 and 2 suggest that domestic firms that supply foreign firms experience a faster rate of increase in efficiency than otherwise identical domestic firms that do not supply foreign firms. The effect is more robust in the firmspecific variables than in the industry-specific variable but its magnitude is of the same order in the firm- and industry-specific variables. Our findings indicate that broadly defined spillovers (technology diffusion) are taking place from foreign firms to their domestic suppliers. The findings are robust across our specifications and are consistent with the evidence in other studies, probably because this is an active transfer of knowledge due to the high quality demands placed on domestic firms by foreign firms. On the other hand, domestic firms that buy from foreign firms (either in the country or outside) or compete with foreign firms in the same industry do not seem to gain positive spillovers, although the signs of the coefficients on Forward and Horizontal tend to be positive. There are two exceptions however: Firms in the service sector and old firms have positive and significant efficiency gains from buying from foreign firms (in the Solow residual equation) and competing with foreign firms (in the Cobb-Douglas equation). We interpret this finding as indicating that in general it is more difficult for a domestic firm to gain efficiency spillovers from a foreign firm when it is in an upstream or competitive relationship with the foreign firm, than when it is in a downstream relationship. In the latter, the foreign firm is directly transferring knowledge whereas in the former two, there are no incentives to do so. Hence the imitative spillovers that one would expect from firms competing in the same product or service market are more difficult to obtain. Moreover, 
if domestic firms are purchasing inputs that are relatively high priced, it may reduce gains in revenue efficiency. Alternatively, if they purchase inputs that are not easily incorporated into the production process (e.g., because their technology is too different, not sufficiently sturdy, etc.), this could reduce efficiency gains. ${ }^{14}$

\section{The Effect of Institutional Environment and Quality of FDI on Spillovers}

As noted above, differences between countries' spillover gains may be caused by differences in the institutional environment and the quality of FDI entering the country. In this section we explore these effects.

Moran et al. (2005) as well as others argue that a country with better intellectual property rights (IPRs) and more openness to market competition and FDI attracts higher quality FDI because by being unconstrained the foreign firms optimize and bring in the latest technology. Conversely, countries that have poor protection of property rights, impose restrictions on ownership or require technology sharing attract FDI with a lower level of technology. Branstetter, Fisman and Foley (2006) have shown that US multinationals respond to changes in the protection of intellectual property in host countries by increasing technology transfer significantly to reforming countries. Their analysis does not consider the impact on reforming countries, but presumably increased technology transfer should lead to greater efficiency in domestic firms interacting with the foreign firms.

Since firms tend to guard their proprietary assets, several studies have concluded that foreign investors are more likely to transfer better technology within wholly owned multinationals subsidiaries than in joint ventures or licensees (e.g., Javorcik and Spartareanu, 2008). Others have shown that in countries with limited rule of law, foreign firms tend to shy away from joint-ownership and choose to invest in wholly-owned

\footnotetext{
${ }^{14}$ For example, the failure of the Polish pre-transition experiment to boost productivity of its firms through the importation of western technology because they were unable to use it is infamous (see, e.g., Terrell, 1992).
} 
ventures (e.g., McCalman, 2004 and Smarzynska and Wei, 2009 who study impact of intellectual property rights and corruption, respectively, on mode of entry).

Another factor that may affect spillovers is the origin of foreign investors. It could be argued that FDI from more developed countries is likely to have a higher level of technology than FDI from less advanced countries. ${ }^{15}$ Hence, domestic firms that are able to grasp this technology will gain more, all other things equal.

Overall, this reasoning and evidence suggests that there should be higher quality FDI in countries with better institutional environments (i.e., less corruption or better rule of law), firms that are wholly-owned by foreign investors and in FDI that comes from more developed countries. Higher quality FDI should yield greater spillovers, ceteris paribus. In our tests, we compare the spillover effects of FDI: a) in different institutional environments, b) from wholly-owned (v. partially-owned) foreign firms, and c) from OECD v. non-OECD countries. However, it should also be noted that in a) and b), the higher quality FDI is motivated by better protection of its proprietary assets. Hence, spillovers may not be larger because it is also more difficult to imitate or reverse engineer the technology of a foreign firm when, for example, the domestic firm is in an environment where intellectual property rights are protected.

We start by testing whether vertical and horizontal spillovers vary systematically with different institutional environments. The BEEPS survey offers a unique opportunity to examine the impact of the characteristics of the institutional environment because it not only has a rich set of variables that capture these factors but, importantly, this information is collected at the firm level. Moreover, BEEPS has large cross-country variation that is usually absent in other studies. In testing for the effect of the institutional environment on the strength of spillovers, it is useful to rewrite our baseline specification as

\footnotetext{
${ }^{15}$ The origin of FDI may matter for spillovers for other reasons as well. If multinationals further from the host country tend to source more from the host than FDI from countries closer to the host or if FDI included within a preferential trade agreement has more access than FDI outside the trade bloc, one might expect greater spillovers (an argument put forth by Javorcik and Spatarenu, 2011).
} 


$$
\Delta \ln Y_{i j}=\alpha \times \Delta \Lambda_{i j}+\beta \times \Delta \mathrm{Z}_{i}+\gamma X_{i j}+\epsilon_{i j}
$$

where $\Delta \ln Y_{i j}$ is growth rate of sales revenue from 2002 to $2005, \Lambda$ is the vector of either industry or firm specific linkage variables, $Z$ is a vector of inputs and $X$ is a set of other controls such as industry and country dummies. Coefficients $\alpha$ measure the strength of linkages.

Let $G$ be a vector of variables that captures institutions. To capture the effect of $G$ on productivity and the strength of spillovers, we modify our baseline specification (6) and estimate the following regression

$$
\Delta \ln Y_{i j}=\alpha \times \Delta \Lambda_{i j}+\theta \times \Delta \Lambda_{i j} \times \Delta G_{j}+\psi \times \Delta G_{j}+\beta \times \Delta \mathrm{Z}_{i}+\gamma X_{i j}+\epsilon_{i j} . \text { (7) }
$$

Among the many variables in the BEEPS that measure the institutional environment, we consider the following two: 1) Bribe (corruption) measured as the percentage of total annual sales typically paid in unofficial payments/gifts to public officials; and 2) Bureaucratic red tape, proxied by the percentage of management's time spent with officials. One would expect spillovers to be more positive when there is less bureaucratic tape or corruption because this will attract higher quality FDI and perhaps because domestic firms in these environments will allocate more resources to be able to absorb technology spillovers. These two variables are constructed by averaging the responses for all the firms in the industry and country in which the firm is located.

We provide separate estimates of the effects of corruption and bureaucratic tape on spillovers in Tables 3 and 4, respectively. Within each table we also report separate estimates of the effect of the institution on spillovers measured by the industry-specific variable (Panel A) and the firm-specific linkage variable (Panel B).

As may be seen from Panel A of Table 3, the estimates obtained from interacting the 2002-2005 rate of change in the intensity of corruption, measured by the Bribe variable, with the 2002-2005 change in the forward, backward and horizontal linkage variables do not reveal any systematic patterns. The coefficients tend to be negative but are not significant except for a dampening effect that an increase in bribes has on horizontal 
spillovers to small firms. The finding that small firms would be more negatively affected by foreign firm presence/competition in more corrupt environments is plausible. It is notable, however, that with this one exception, an increase in the intensity of corruption (Bribe) has neither a direct nor an interactive effect on the rate of change of efficiency of any other type of domestic firms. The firm-specific estimates in Panel B of Table 3 are consistent with those in Panel A in showing that corruption does not seem to strongly affect vertical spillovers. The only significant negative effect is on large firms selling to foreign firms. Interestingly the magnitude of the coefficient for the similar industry variable (interaction between Bribe and Backward) is also greatest for large firms although it is not significant.

Table 4 shows the effects of bureaucratic red tape (the percentage of manager's time spent with officials) on vertical and horizontal spillovers using the industry- and firmspecific variables in Panels A and B, respectively. The coefficients in both panels indicate that an increase in the time spent with officials tends to dampen spillovers to upstream firms (i.e., Backward, SalesFF, but not Exports), as the coefficients are negative, but only significant for small and old firms (for Backward) as well as for large and service sector firms (for Sales FF). On the other hand, large firms and those established before 1991 tend to benefit in terms of revenue efficiency from an increased presence of foreign firms in their industry (Horizontal) and the benefit rises with greater interaction with government officials (Panel A). In these situations, the time spent with officials may not reflect the burden of red tape, but rather the net effect of the ability of managers to obtain better terms for doing their business. Finally, we consistently find there are no spillovers to downstream domestic firms (Forward and Imports), with the exception for firms in the service sector (and old firms though not significant at conventional levels in this specification), and spending time with managers does not improve or detract from this.

The specification in equation (7) is of course very demanding on the data because it identifies all effects only from the 2002-2005 variation and does not exploit the sizable 
cross-country and cross-industry variation at a given point in time. We have therefore also estimated a specification that exploits the level rather than rate of change of corruption. In particular, we have revised equation (7) to include the 2002 levels of the institutional variables as follows:

$$
\Delta \ln Y_{i j}=\alpha \times \Delta \Lambda_{i j}+\theta \times \Delta \Lambda_{i j} \times G_{j}^{2002}+\psi \times G_{j}^{2002}+\beta \times \Delta Z_{i}+\gamma X_{i j}+\epsilon_{i j}
$$

When we estimate equation (8), the estimates of $\theta$ and $\psi$ (not reported here) are not significantly different from zero for the 2002 levels of bribe or manager's time.

Since the role of institutions is generally considered to be very important, we have proceeded with additional lines of investigation. We examine whether the institutional variables have a systematic effect when they are measured at the country level rather than at the industry and country level. This corresponds to the notion that corruption and other institutional features in a given country has a uniform effect on all firms rather than affecting firms in some industries more than those in others. We therefore calculate new 2002 measures of bribe and manager's time as the average responses to these two respective questions by all firms in a given country. We rank the 17 countries by each of these two indicators and divide them into three groups for each indicator. Next we estimate a specification that interacts each of these categorical variables of corruption (managers' time) with the three linkage variables. The results (not reported here) indicate that there is no systematic effect. Using country-level indicators, we hence cannot find any evidence of an effect of the institutional environment in terms of the level of corruption or bureaucratic red tape on the strength of spillovers.

Next, to test the hypotheses regarding the strength of spillovers and quality of FDI as proxied by degree of foreign ownership (whole v. partial) and country of origin of the FDI, we re-estimate equation (1) with new variables for the backward, forward, and horizontal linkages. The foreign presence variable, $F P_{j}$, is recalculated for share of output 
by wholly-owned foreign firms v. partially-owned ones and for share of output produced by FDI from OECD countries v. non-OECD countries. Specifically, we estimate

$$
\Delta \ln Y_{i j}=\alpha_{W} \times \Delta \Lambda_{i j}^{\text {whole }}+\alpha_{P} \times \Delta \Lambda_{i j}^{\text {partial }}+\beta \times \Delta Z_{i}+\gamma X_{i j}+\epsilon_{i j},
$$

where $\Lambda_{i j}^{\text {whole }}$ is a vector of linkage variables computed according to equations (2)-(4) with $s_{i}=1$ in (2) - i.e., linkage variables for wholly owned firms only, and $\Lambda_{i j}^{p a r t i a l}$ is a vector of linkage variables computed according to (2)-(4) with $s_{i}<1$ in (2)-i.e., linkage variables for partially owned firms only. The findings for these proxies of the "quality of FDI" are presented in Table 5.

As may be seen from Panel A of Table 5, apart from the backward linkages one cannot reject the hypothesis that the linkage coefficients for wholly and partially owned foreign firms are pair-wise identical. As to the backward linkage, the positive effect observed on the entire sample earlier appears to be driven by firms with partial foreign ownership (especially those that are large and new), suggesting that the combination of local and foreign know-how is superior to the know-how generated by foreign ownership alone.

The results in Panel B of Table 5 indicate that FDI from advanced economies does not uniformly lead to higher efficiency spillovers than FDI from less developed countries. On the contrary, FDI from developing countries has a stronger positive effect more often than FDI from advanced economies. Thus FDI from OECD results in a positive backward linkage effect among new firms and those in services, while FDI from non-OECD has a positive forward linkage effect among large firms, old firms and in the sample as a whole. Non-OECD FDI has a positive forward linkage effect in large firms, old firms and those in services, while OECD FDI does not have a positive linkage effect for any category of firms. Finally, one cannot reject the hypothesis that the horizontal linkage effect of OECD and non-OECD FDI is the same for all categories of firms except the old firms, where the nonOECD FDI registers a strong positive linkage effect, while the corresponding effect of OECD FDI is insignificant. 
The estimates in Table 5 indicate that for the most part there appears to be no systematic difference in productivity spillovers from wholly v. partially owned foreign firms or from FDI from OECD v. non-OECD countries. If anything spillovers are more frequently greater for FDI in partially (rather than wholly) owned foreign firms and FDI from non-OECD rather than OECD countries. Hence, neither the conjecture that whollyowned foreign firms have higher levels of technology than partially-owned ones, nor the conjecture that the quality of FDI from OECD countries is better than that from non-OECD countries is borne out in terms of the estimated spillover effects. However, we recognize that spillovers may not be greater the higher the quality/technology of FDI if the foreign firm is better able to protect its proprietary asset or if local firms are not able to absorb them. Hence, for example, the lower level technology in the non-OECD FDI may be more easily absorbed in these countries. Another story consistent with these findings would be that the OECD FDI is better able to protect its proprietary assets than non-OECD FDI. We are not able to distinguish between these hypotheses with our data.

\section{6. “Absorptive Capacity” of the Firm and Spillovers}

A popular hypothesis in the literature is that the extent to which local firms benefit from FDI spillovers depends on the level of their technology (efficiency) or human capital. Acemoglu, Aghion and Zilibotti (2003) and Aghion, Bloom, Blundell, Griffith, and Howitt (2005) for instance use a Schumpeterian model to predict that firms that are close to the efficiency frontier benefit more from foreign presence than firms that are far from the frontier.

The empirical problem for testing the hypothesis with respect to the "efficiency or technology gap" is that the level of efficiency is not observed and thus it is hard to compute the distance to the frontier at the firm level. ${ }^{16}$ We tackle this problem in the following way.

\footnotetext{
${ }^{16}$ We do not use stochastic frontier analysis because the distance from the frontier interacted with other variables is correlated with the residual, which includes the level of technology.
} 
Since there is substantial evidence that foreign firms are more efficient than domestic firms in the developing countries, we assume that foreign firms embody the efficiency frontier. Firms that are similar to foreign firms along observed characteristics are likely to have efficiency (technology) that is close to that of the foreign-owned counterparts. If observed characteristics of domestic firms are different from observed characteristic of the foreignowned firms, the domestic firms are likely to use a technology different from the technology used by foreign-owned firms. At the minimum, one can interpret this difference as the distance from the business practice of foreign-owned firms.

To construct such a metric of discrepancy, we draw on the literature on matching (e.g., Rosembaum 2002). Specifically, we use the Mahalanobis distance, i.e., the distance of domestic firm $i$ to a foreign firm as measured by

$$
d_{i}=\min _{\mathrm{j} \in \mathrm{F}}\left\{\left(x_{i}^{D}-x_{j}^{F}\right)^{\prime} S_{x}^{-1}\left(x_{i}^{D}-x_{j}^{F}\right)\right\}^{1 / 2}
$$

where $\boldsymbol{x}$ are observed characteristics, $F$ and $D$ denote foreign-owned and domestic companies and $S_{x}$ is the covariance matrix of the vector of observed characteristics $x$. We take the minimum over all possible distances since efficiency/technology (business practices and models) can vary across foreign-owned firms.

The vector of observed characteristics contains the logarithm of capital stock and number of employees, structure of the employment (educational attainment in terms of the number of employees that completed primary school, vocational school, secondary school, or college; and skill level in terms of the number of employees that are managers, skilled workers, unskilled workers, or professional employees), type of location (capital, large city, mediums-size city, town), industry (NACE 2-digit level), export status (Yes/No), and country. We match firms by industry and country exactly, i.e., domestic firms can be matched only to foreign-owned firms in the same industry and country. Since the distance is strongly skewed, we take Distance $_{i} \equiv \log \left(1+d_{i}\right)$ as the distance from the frontier in our specification. 
To test the hypothesis that distance to the frontier affects the strength of spillovers, we modify the baseline specification (1) in a manner similar to the modification that tests for the effects of institutions:

$\Delta \ln Y_{i j}=\alpha \times \Delta \Lambda_{i j}+\theta \times \Delta \Lambda_{i j} \times$ Distance $_{i}+\psi \times$ Distance $_{i}+\beta \times \Delta Z_{i}+\gamma X_{i j}+\epsilon_{i j}$

The effect of distance on the strength of vertical and horizontal linkages is captured by the coefficient on the interaction of Distance with linkage $\Lambda$.

The key findings on the efficiency gap are reported in Table 6. The coefficients on Distance are consistent with the theoretical prediction by showing that domestic firms that are further away from foreign firms are less efficient in generating revenue from inputs than firms that are closer to foreign firms. Coefficients on the interactions of distance and linkages are also by and large negative, suggesting that firms that are further from foreign firms tend to have smaller horizontal and vertical spillovers, but the coefficients are only statistically significant for backward spillovers in old firms and horizontal spillovers in manufacturing. The prediction that firms that are close to the technological frontier benefit more from foreign presence than firms that are far from the technological frontier hence receives only limited statistical support in our data and is consistent with the diverse findings in the literature and the non-findings by Abraham, Konings, and Slootmaeker (2006) for China.

\section{Conclusions}

Using data from 17 transition economies, we advance our understanding of the magnitude of vertical and horizontal spillovers of multinational enterprises (foreign firms) on the efficiency of domestic firms by (i) estimating the direct backward spillover of foreign firms on firms that sell to foreign firms, in addition to estimating the usual industry-level spillover on all firms, (ii) providing much larger comparative evidence than other studies, (iii) generating estimates not only for manufacturing but also for services, (iv) analyzing not only large but also small firms that tend to be the new entrepreneurs and engines of growth, (v) 
using a broader measure of efficiency than other studies by analyzing how efficiently firms generate sales revenue, taking into account inputs of capital, labor and materials, (vi) including in the analysis of vertical spillovers the concept of selling or buying from outside of the country, (vii) shedding light on the impact of a country's institutional environment on the strength of vertical and horizontal spillovers, and (viii) testing whether FDI from more v. less advanced countries and FDI in the form of a wholly foreign-owned firms versus joint ventures has larger spillovers, and (ix) addressing the question of whether the efficiency/technology gap of local firms relative to foreign firms affects the strength of spillovers.

In our baseline estimates we provide support for the findings of recent single-country studies that there are positive backward spillovers on efficiency, using an industry-level variable based on input-output tables. We extend these findings by showing that our firmspecific measure of backward spillovers and the share of sales exported generate significant positive effects among virtually all categories of firms, while the industry-level measure used in existing studies generates significant estimates only in large firms, new firms and firms in manufacturing. Hence, we present an important finding that interaction with foreign firms benefits a given domestic firm through its direct interaction with a foreign firm and indirectly through the interactions of other domestic firms with foreign firms.

Our finding that forward and horizontal spillovers are usually insignificant is also in line with the bulk of the literature and consistent with the notion that these types of spillovers are less likely to occur than backward spillovers. However, we do find that well established (old) firms and firms operating in a sector where methods and skills of production are relatively visible (services) benefit from the presence of foreign competitors and from supplying to foreign firms. Hence, we identify a pattern that supplying to a foreign firm, whether in the host country or outside of the country, has knowledge spillover effects whereas purchasing from foreign firms, domestically or from abroad, in general does not. 
Our analysis of the performance effects of key institutional variables focuses on bribes (corruption) to public officials and regulatory burden as measured by the time that top management spends with public officials. We find that, by and large, these aspects of institutions do not have negative effects on performance. Our findings that key measures of institutions have surprisingly little effect on firm efficiency - directly or indirectly through spillovers - raises issues about the magnitude of their effect v. the researchers' ability to measure them.

We also test for the hypothesis that firms with higher quality FDI provide greater spillovers to domestic firms. Following the literature, we assume that wholly foreignowned firms have higher quality than partially foreign-owned firms and that FDI from more advanced (OECD) countries is of higher quality. We also explore whether differentiated spillovers vary with the host country institutional environments. We find no systematic support for any of these hypotheses.

We contribute to the large literature testing whether firms that are closer to the efficiency/technological frontier or have a higher level of human capital benefit more from foreign presence. We find that distance from the frontier tends to dampen the horizontal and vertical spillovers but it is only significant for horizontal spillovers in manufacturing and backward spillovers in old firms.

In sum, while the literature in this area often reports insignificant effects, we find some significant effects across the board (e.g., selling to foreign firms and exporting) and show that other significant effects are detectable in specific categories of firms or in nonlinear (interactive) specifications. Our analysis points to the need for future research to take into account heterogeneous spillover effects. It also highlights the value of having firm-level linkage variables in addition to the usual industry-level measures because some spillovers are confined to the firm actually supplying a foreign firm rather than spread over many firms in a given industry. Finally, our results call for deeper analyses of how institutional factors affect the strength of spillovers. 


\section{References}

Abraham, F., Josef Konings and V. Slootmaekers (2006) "FDI Spillovers, Firm Heterogeneity and Degree of Ownership: Evidence from Chinese Manufacturing," Unpublished Paper, Department of Economics, Catholic University of Leuven, November.

Acemoglu, Daron, Philippe Aghion, and Fabrizio Zilibotti (2003) "Vertical Integration and Distance to Frontier," Journal of the European Economic Association 1(2-3): 630638.

Aghion, Philippe, Nick Bloom, Richard Blundell, Rachel Griffith and Peter Howitt (2005) "Competition and Innovation: An Inverted U Relationship," Quarterly Journal of Economics 120(2): 701-728.

Aghion, Philippe, Robin Burgess, Stephen Redding, and Fabrizio Zilibotti (2005) "Entry Liberalization and Inequality in Industrial Performance," Journal of the European Economic Association 3(2-3): 291-302.

Aitken, Brian J. and Ann E. Harrison (1999) "Do Domestic Firms Benefit from Foreign Direct Investment? Evidence from Venezuela." American Economic Review 89(3): 605-618.

Blalock, Garrick and Paul J. Gertler (2002) "Firm Capabilities and Technology Adoption: Evidence from Foreign Direct Investment in Indonesia," Working paper Department of Applied Economics and Management, Cornell University. Ithaca, NY.

(2008) "Welfare Gains from Foreign Direct Investment Through Technology Transfer to Local Suppliers," Journal of International Economics 74(2): 402-421.

(2005) "Foreign Direct Investment and Externalities: The Case for Public Intervention," in T. H. Moran, E. M. Graham and M Blomstrom (eds.) Does Foreign Direct Investment Promote Development? Institute for International Economics, Center for Global Development: Washington, D.C.

Borensztein, E., J. De Gregorio and J-W. Lee (1998) "How Does Foreign Direct Investment Affect Economic Growth?" Journal of International Economics 45(1): 115-135.

Branstetter, Lee G., Raymand Fisman and C. Fritz Foley (2006) "Do Stronger Intellectual Property Rights Increase International Technology Transfer? Empirical Evidence from U.S. Firm-Level Panel Data," Quarterly Journal of Economics 121(1): 321349.

Caves, Richard (1974) "Multinational Firms, Competition and Productivity in HostCountry Markets," Economica 41(162): 176-193.

Cohen, Wesley and Daniel Levinthal (1989) "Innovation and Learning: The Two Faces of R\&D," Economic Journal 99(397): 569-596.

Djankov, Simeon and Bernard Hoekman (2000) "Foreign Investment and Productivity Growth in Czech Enterprises," The World Bank Economic Review 14(1): 49-64.

Findlay, Ronald (1978) "Relative Backwardness, Direct Foreign Investment and the Transfer of Technology: A Simple Dynamic Model," Quarterly Journal of Economics, 92(1): 1-16. 
Fons-Rosen, Christian, Sebnem Kalemli-Ozcan, Bent E. Sørensen, Carolina VillegasSanchez, and Vadym Volosovych (2013) "Quantifying Productivity Gains from Foreign Investment,” NBER Working Paper 18920.

Girma, Sourafel (2005) "Absorptive Capacity and Productivity Spillovers from FDI: A Threshold Regression Analysis," Oxford Bulletin of Economics and Statistics 67(3): 281-306.

Girma, Sourafel, David Greenaway and Katharine Wakelin (2001) "Who Benefits from Foreign Direct Investment in the UK?" Scottish Journal of Political Economy 48(2): 119-133.

Girma, Sourafel, Holger Gorg and Mauro Pisu (2008) "Exporting, Linkages and Productivity Spillovers from Foreign Direct Investment," Canadian Journal of Economics 41(1): 320-340.

Görg, Holger and David Greenaway (2003) "Much Ado About Nothing? Do Domestic Firms Really Benefit from Foreign Direct Investment?" IZA Discussion Papers 944, Institute for the Study of Labor (IZA).

Gorodnichenko, Yuriy, Jan Svejnar and Katherine Terrell (2010) "Globalization and Innovation in Emerging Markets," American Economic Journal-Macroeconomics 2(2): 194-226.

Haddad, Mona and Ann E. Harrison (1993) “Are There Positive Spillovers from Foreign Direct Investment?” Journal of Development Economics 42(1): 51-74.

Haskel, Jonathan E., Sonia C. Pereira and Matthew J. Slaughter (2007) "Does Inward Foreign Direct Investment Boost the Productivity of Domestic Firms?" The Review of Economics and Statistics 89(3): 482-496.

Javorcik, Beata Smarzynska (2004) "The Composition of FDI and Protection of Intellectual Property Rights. Evidence from Transition Economies," European Economic Review 48(1): 39-62.

Javorcik, Beata Smarzynska and Kamal Saggi (2011) "Technological Asymmetry and the Mode of Foreign Investors," Economic Inquiry 48(2): 415-433.

Javorcik, Beata Smarzynska and Mariana Spatareanu (2011) "Does It Matter Where You Come from? Vertical Spillovers from FDI and Investor Nationality," Journal of Development Economics 96(1): 126-138.

Javorcik, Beata Smarzynska and Mariana Spatareanu (2008) "To Share or Not to Share: Does Local Participation Matter for FDI Spillovers?" Journal of Development Economics 85(1-2): 194-217.

Keller, Wolfgang and Stephen R. Yeaple (2009) "Multinational Enterprises, International Trade and Productivity Growth: Firm Level Evidence from the U.S." The Review of Economics and Statistics 91(4): 821-831.

Kinoshita, Yuko (2000) "R\&D and Technology Spillovers through FDI: Innovation and Absorptive Capacity," CEPR Working Paper No. 2775.

Konings, Jozef (2001) "The Effects of Foreign Direct Investment on Domestic Firms: Evidence from Firm Level Panel Data in Emerging Economies," Economics of Transition 9(3): 619-633.

Kosova, Renata (2010) "Do Foreign Firms Crowd Out Domestic Firms? Evidence from the Czech Republic," Review of Economics and Statistics 92(4): 861-881.

Lall, Sanjay (1980) "Vertical Inter-Firm Linkages in LDCs: An Empirical Study," Oxford Bulletin of Economics and Statistics 42(3): 203-226. 
Lin, Ping and Kamal Saggi (2007) "Multinational Firms, Exclusivity and Backward Linkages," Journal of International Economics 71(1): 206-220.

McCalman, Phillip (2004) "Foreign Direct Investment and Intellectual Property Rights:

Evidence from Hollywood's Global Distribution of Movies and Videos," Journal of International Economics 62(1): 107-123.

Moran, Theodore H., Edward M. Graham and Magnus Blomstrom (2005) (eds.) Does Foreign Direct Investment Promote Development? Institute for International Economics, Center for Global Development: Washington, D.C.

Rosembaum, Paul R. (2002) Observational Studies. Springer-Verlag.

Sabirianova, Klara, Jan Svejnar and Katherine Terrell (2005) "Distance to the Efficiency Frontier and FDI Spillovers," Journal of the European Economic Association 3(23): 576-586.

Sabirianova, Klara, Jan Svejnar and Katherine Terrell (2012) "Foreign Investment, Corporate Ownership and Development: Are Firms in Emerging Markets Catching up to the World Standard?" Review of Economics and Statistics 94(4): 981-999.

Schoors, Koen and Bartoldus van der Tol (2001) "The Productivity Effect of Foreign Ownership on Domestic Firms in Hungary," presented at the EAE Conference in Philadelphia, PA, Oct. 11-14, 2001.

Sembenelli, Alessandro and George Siotis (2002) "Foreign Direct Investment, Competitive Presusure and Spillovers, An Empirical Analysis of Spanish Firm Level Data," Centro Studi Luca D’Agliano Development Studies Work Paper No. 169.

Smarzynska, Beata and Shang-Jin Wei (2009) "Corruption and Cross Border Investment: Firm-Level Evidence," Journal of International Money and Finance 28(4): 605624.

Stancik, Juraj (2007) "Horizontal and Vertical FDI Spillovers: Recent Evidence from the Czech Republic," CERGE-EI Working Papers wp340.

Terrell, Katherine (1992) "Productivity of Western and Domestic Capital in Polish Industry," Journal of Comparative Economics 16(3): 494-514. 
Table 1. Spillover Effects on Revenue Efficiency Using Cobb-Douglas Production Function

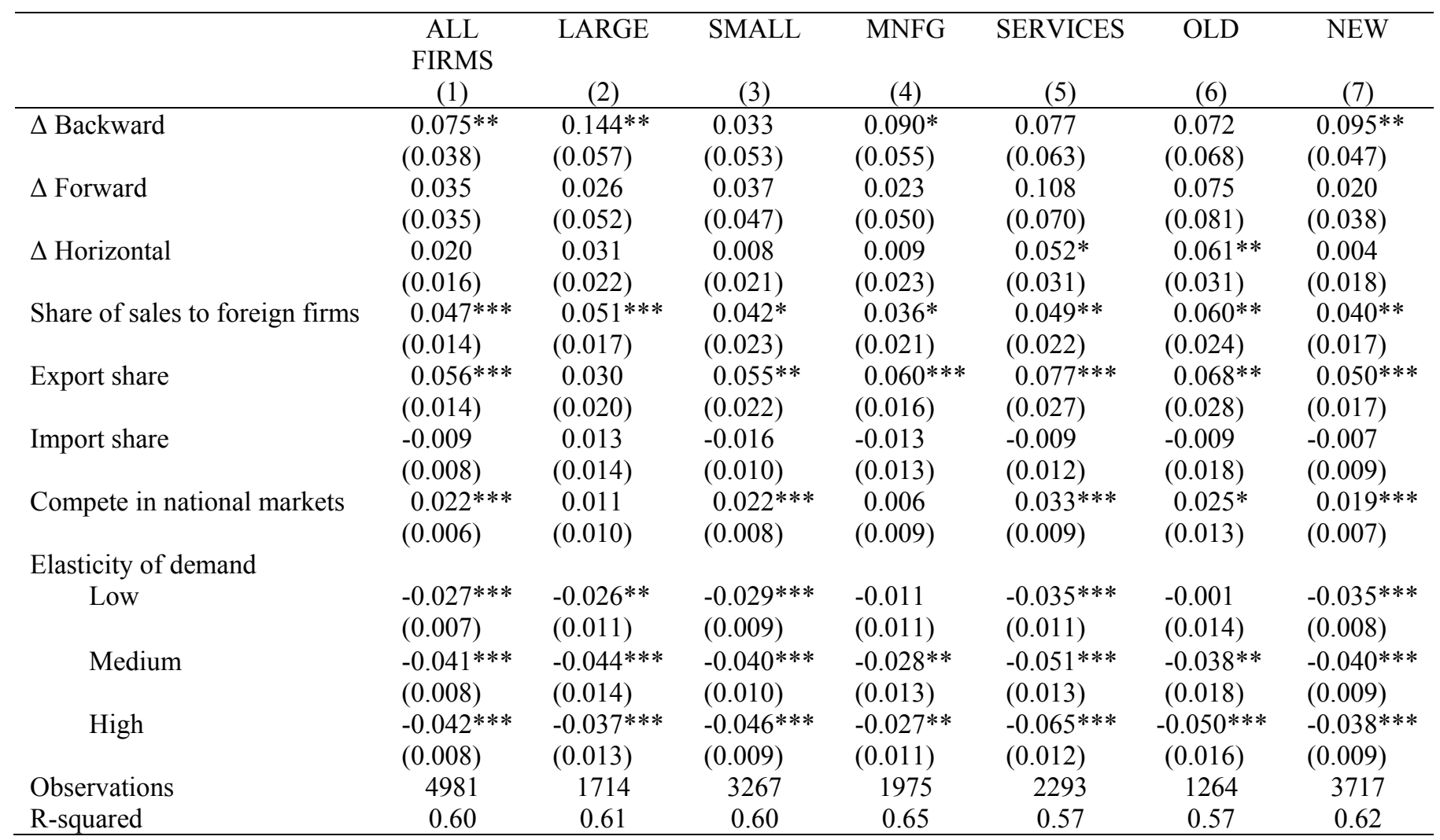

Note: The table reports the estimated effects on revenue efficiency using a Cobb-Douglas function, where the dependent variables is the growth rate of sales revenues; the independent variables include the growth rate of three inputs (utilization adjusted capital, the number of employees and materials), country and industry fixed effects, and the reported variables. See text for definition of variables. Large firms are defined as firms with more than 30 employees. MNFG = manufacturing firms according to NACE classification. OLD firms are defined as firms established before 1991. NEW firms are established in 1991 or after 1991. The benchmark group for the elasticity of demand is "inelastic." Robust clustered standard errors in parentheses; $*$ significant at $10 \% ; * *$ significant at $5 \% ; * * *$ significant at $1 \%$. 
Table 2. Spillover Effects on Revenue Efficiency Using the Solow Residual

\begin{tabular}{lccccccc}
\hline & ALL & LARGE & SMALL & MNFG & SERVICES & OLD & NEW \\
& FIRMS & & & & & & \\
& $(1)$ & $(2)$ & $(3)$ & $(4)$ & $(5)$ & $(6)$ & $(7)$ \\
\hline$\Delta$ Backward & 0.071 & $0.157^{* *}$ & 0.023 & 0.059 & 0.096 & 0.071 & 0.090 \\
& $(0.045)$ & $(0.067)$ & $(0.062)$ & $(0.067)$ & $(0.075)$ & $(0.081)$ & $(0.055)$ \\
$\Delta$ Forward & 0.039 & 0.055 & 0.022 & 0.027 & $0.161^{* *}$ & $0.196^{* *}$ & -0.001 \\
& $(0.041)$ & $(0.064)$ & $(0.054)$ & $(0.061)$ & $(0.082)$ & $(0.091)$ & $(0.046)$ \\
$\Delta$ Horizontal & 0.016 & 0.043 & -0.001 & 0.017 & 0.051 & $0.071^{* *}$ & -0.002 \\
& $(0.018)$ & $(0.026)$ & $(0.024)$ & $(0.027)$ & $(0.035)$ & $(0.034)$ & $(0.022)$ \\
Share of sales to foreign firms & $0.048^{* * *}$ & 0.036 & $0.058^{* *}$ & 0.027 & $0.049^{*}$ & $0.057^{*}$ & $0.044^{* *}$ \\
& $(0.017)$ & $(0.022)$ & $(0.026)$ & $(0.023)$ & $(0.029)$ & $(0.031)$ & $(0.020)$ \\
Export share & $0.076^{* * *}$ & $0.072^{* * *}$ & $0.060^{* *}$ & $0.100^{* * *}$ & $0.080^{* * *}$ & $0.107^{* * *}$ & $0.059^{* * *}$ \\
& $(0.016)$ & $(0.022)$ & $(0.026)$ & $(0.018)$ & $(0.030)$ & $(0.029)$ & $(0.020)$ \\
Import share & -0.009 & 0.008 & -0.014 & -0.013 & -0.009 & -0.029 & -0.002 \\
& $(0.010)$ & $(0.016)$ & $(0.012)$ & $(0.014)$ & $(0.015)$ & $(0.019)$ & $(0.011)$ \\
Compete in national markets & $0.026^{* * *}$ & 0.005 & $0.031^{* * *}$ & 0.008 & $0.043^{* * *}$ & 0.024 & $0.024^{* * *}$ \\
& $(0.007)$ & $(0.012)$ & $(0.009)$ & $(0.011)$ & $(0.011)$ & $(0.015)$ & $(0.008)$ \\
Elasticity of demand & & & & & & & $-0.043^{* * *}$ \\
Low & $-0.031^{* * *}$ & $-0.026^{*}$ & $-0.033^{* * *}$ & -0.003 & $-0.043^{* * *}$ & 0.004 & -0.004 \\
Medium & $(0.008)$ & $(0.014)$ & $(0.011)$ & $(0.013)$ & $(0.012)$ & $(0.017)$ & $(0.010)$ \\
& $-0.037^{* * *}$ & $-0.042^{* * *}$ & $-0.035^{* * *}$ & -0.023 & $-0.047^{* * *}$ & -0.031 & $-0.038^{* * *}$ \\
High & $(0.010)$ & $(0.016)$ & $(0.012)$ & $(0.015)$ & $(0.015)$ & $(0.020)$ & $(0.011)$ \\
& $-0.041^{* * *}$ & -0.018 & $-0.051^{* * *}$ & -0.014 & $-0.076^{* * *}$ & $-0.032^{*}$ & $-0.043^{* * *}$ \\
Observations & $(0.009)$ & $(0.015)$ & $(0.011)$ & $(0.014)$ & $(0.013)$ & $(0.019)$ & $(0.010)$ \\
R-squared & 4991 & 1716 & 3275 & 1979 & 2297 & 1267 & 3724 \\
\hline
\end{tabular}

Note: The table reports the estimated effects on revenue efficiency using the Solow residual, where the dependent variables is the growth rate of sales revenues; the independent variables include the rates of change of three inputs (utilization adjusted capital, the number of employees and materials) whose cost shares are allowed to vary by industry, as well as country and industry fixed effects, and the reported variables. See text for definition of variables. Large firms are defined as firms with more than 30 employees. MNFG = manufacturing firms according to NACE classification. OLD firms are defined as firms established before 1991. NEW firms are established in 1991 or after 1991. The benchmark group for the elasticity of demand is "inelastic." Robust clustered standard errors in parentheses; * significant at $10 \%$; ** significant at $5 \%$; *** significant at $1 \%$. 
Table 3: Effect of Bribes on the Strength of Spillovers and Revenue Efficiency

\begin{tabular}{|c|c|c|c|c|c|c|c|}
\hline & $\begin{array}{c}\text { ALL } \\
(1)\end{array}$ & $\begin{array}{c}\text { LARGE } \\
(2)\end{array}$ & $\begin{array}{c}\text { SMALL } \\
(3)\end{array}$ & $\begin{array}{c}\text { MNFG } \\
(4)\end{array}$ & $\begin{array}{l}\text { SERV } \\
(5)\end{array}$ & $\begin{array}{c}\text { OLD } \\
(6)\end{array}$ & $\begin{array}{c}\text { NEW } \\
(7) \\
\end{array}$ \\
\hline \multicolumn{8}{|c|}{ Panel A: Industry Level Linkages } \\
\hline \multirow[t]{2}{*}{$\Delta$ Backward } & $0.084 * *$ & $0.140 * *$ & 0.045 & 0.089 & 0.098 & 0.093 & $0.102 * *$ \\
\hline & $(0.039)$ & $(0.060)$ & $(0.054)$ & $(0.057)$ & $(0.066)$ & $(0.072)$ & $(0.048)$ \\
\hline \multirow[t]{2}{*}{$\Delta$ Forward } & 0.026 & 0.032 & 0.028 & 0.039 & 0.072 & 0.069 & 0.007 \\
\hline & $(0.042)$ & $(0.068)$ & $(0.053)$ & $(0.071)$ & $(0.077)$ & $(0.096)$ & $(0.046)$ \\
\hline \multirow[t]{2}{*}{$\Delta$ Horizontal } & 0.020 & $0.041 *$ & 0.002 & 0.008 & 0.039 & $0.072 * *$ & 0.004 \\
\hline & $(0.016)$ & $(0.023)$ & $(0.021)$ & $(0.023)$ & $(0.030)$ & $(0.032)$ & $(0.018)$ \\
\hline \multirow[t]{2}{*}{$\Delta$ Backward $* \Delta$ Bribe } & 0.393 & -1.308 & 0.868 & -0.050 & 1.242 & -1.161 & 1.287 \\
\hline & $(1.664)$ & $(2.368)$ & $(2.437)$ & $(2.575)$ & $(3.595)$ & $(3.026)$ & $(2.057)$ \\
\hline \multirow[t]{2}{*}{$\Delta$ Forward $* \Delta$ Bribe } & -0.803 & 0.696 & -1.135 & 0.583 & -3.905 & -0.922 & -1.044 \\
\hline & $(1.263)$ & $(1.695)$ & $(1.935)$ & $(1.718)$ & $(3.399)$ & $(2.806)$ & $(1.406)$ \\
\hline \multirow[t]{2}{*}{$\Delta$ Horizontal $* \Delta$ Bribe } & -0.608 & 0.943 & $-1.515 * *$ & -0.475 & -0.350 & -0.513 & -0.470 \\
\hline & $(0.613)$ & $(0.767)$ & $(0.750)$ & $(1.059)$ & $(1.194)$ & $(1.174)$ & $(0.741)$ \\
\hline \multirow[t]{2}{*}{$\Delta$ Bribe } & 0.118 & 0.306 & -0.044 & 0.131 & 0.035 & 0.426 & 0.148 \\
\hline & $(0.146)$ & $(0.221)$ & $(0.191)$ & $(0.293)$ & $(0.197)$ & $(0.298)$ & $(0.169)$ \\
\hline Observations & 4972 & 1710 & 3262 & 1973 & 2289 & 1261 & 3711 \\
\hline \multirow[t]{2}{*}{ R-squared } & 0.60 & 0.62 & 0.60 & 0.65 & 0.57 & 0.57 & 0.62 \\
\hline & & Panel B & $\mathrm{cm}$ Level L & kages & & & \\
\hline \multirow[t]{2}{*}{ Sales to foreign firms (SalesFF) } & $0.039 * *$ & $0.039 * *$ & 0.036 & 0.031 & $0.041^{*}$ & $0.051 * *$ & 0.031 \\
\hline & $(0.016)$ & $(0.018)$ & $(0.028)$ & $(0.026)$ & $(0.022)$ & $(0.023)$ & $(0.021)$ \\
\hline \multirow[t]{2}{*}{ Exports } & $0.063 * * *$ & $0.040 *$ & $0.062 * *$ & $0.075 * * *$ & $0.083 * * *$ & $0.090 * * *$ & $0.052 * * *$ \\
\hline & $(0.016)$ & $(0.023)$ & $(0.025)$ & $(0.021)$ & $(0.029)$ & $(0.033)$ & $(0.019)$ \\
\hline \multirow[t]{2}{*}{ Imports } & -0.010 & 0.014 & -0.018 & -0.024 & -0.008 & -0.002 & -0.010 \\
\hline & $(0.009)$ & $(0.016)$ & $(0.011)$ & $(0.015)$ & $(0.014)$ & $(0.018)$ & $(0.011)$ \\
\hline \multirow[t]{2}{*}{ SalesFF $* \Delta$ Bribe } & -0.947 & $-1.462 * *$ & -0.509 & -0.654 & -0.936 & -1.106 & -0.914 \\
\hline & $(0.672)$ & $(0.728)$ & $(1.191)$ & $(1.123)$ & $(0.889)$ & $(1.412)$ & $(0.828)$ \\
\hline \multirow[t]{2}{*}{ Exports $* \Delta$ Bribe } & 0.550 & 0.694 & 0.608 & 0.976 & 0.640 & 1.068 & 0.140 \\
\hline & $(0.518)$ & $(0.764)$ & $(0.720)$ & $(0.936)$ & $(0.583)$ & $(0.878)$ & $(0.643)$ \\
\hline \multirow[t]{2}{*}{ Imports $* \Delta$ Bribe } & -0.016 & 0.133 & -0.122 & -0.723 & 0.176 & 0.923 & -0.185 \\
\hline & $(0.322)$ & $(0.460)$ & $(0.437)$ & $(0.541)$ & $(0.478)$ & $(0.598)$ & $(0.383)$ \\
\hline \multirow[t]{2}{*}{$\Delta$ Bribe } & 0.137 & 0.249 & -0.005 & 0.341 & 0.013 & 0.140 & 0.235 \\
\hline & $(0.180)$ & $(0.267)$ & $(0.242)$ & $(0.333)$ & $(0.242)$ & $(0.361)$ & $(0.208)$ \\
\hline Observations & 4972 & 1710 & 3262 & 1973 & 2289 & 1261 & 3711 \\
\hline R-squared & 0.60 & 0.62 & 0.60 & 0.65 & 0.57 & 0.57 & 0.62 \\
\hline
\end{tabular}

Note: The table reports the estimated spillover effects on revenue efficiency using the specification in equation (8) in the paper. The bribe variable is constructed as the sum of the answers to the following two questions: 1) "On average, what percent of total annual sales do firm's like yours typically pay in unofficial payments/gifts to public officials?"; 2) "When firms in your industry do business with the government, what percent of the contract value would be typically paid in additional or unofficial payments/gifts to secure the contract?" To reduce noise, we use the average value of bribes in a given industry and country. Robust clustered standard errors in parentheses; * significant at $10 \%$; * significant at $5 \% ; * * *$ significant at $1 \%$. 
Table 4: Effect of Manager's Time Spent with Officials on the Strength of Spillovers and Revenue Efficiency

\begin{tabular}{|c|c|c|c|c|c|c|c|}
\hline & $\begin{array}{l}\text { ALL } \\
(1)\end{array}$ & $\begin{array}{l}\text { LARGE } \\
(2)\end{array}$ & $\begin{array}{l}\text { SMALL } \\
\text { (3) }\end{array}$ & $\begin{array}{l}\text { MNFG } \\
\text { (4) }\end{array}$ & $\begin{array}{l}\text { SERV } \\
(5)\end{array}$ & $\begin{array}{l}\text { OLD } \\
(6)\end{array}$ & $\begin{array}{l}\text { NEW } \\
(7)\end{array}$ \\
\hline \multicolumn{8}{|c|}{ Panel A: Industry Level Linkages } \\
\hline$\Delta$ Backward & $\begin{array}{c}0.060 \\
(0.039)\end{array}$ & $\begin{array}{l}0.131 * * \\
(0.057)\end{array}$ & $\begin{array}{c}-0.007 \\
(0.057)\end{array}$ & $\begin{array}{c}0.086 \\
(0.060)\end{array}$ & $\begin{array}{c}0.041 \\
(0.072)\end{array}$ & $\begin{array}{c}0.014 \\
(0.073)\end{array}$ & $\begin{array}{l}0.101^{* *} \\
(0.049)\end{array}$ \\
\hline$\Delta$ Forward & $\begin{array}{c}0.044 \\
(0.036)\end{array}$ & $\begin{array}{c}0.025 \\
(0.051)\end{array}$ & $\begin{array}{c}0.064 \\
(0.050)\end{array}$ & $\begin{array}{c}0.021 \\
(0.053)\end{array}$ & $\begin{array}{c}0.155^{*} \\
(0.080)\end{array}$ & $\begin{array}{c}0.122 \\
(0.085)\end{array}$ & $\begin{array}{c}0.018 \\
(0.039)\end{array}$ \\
\hline$\Delta$ Horizontal & $\begin{array}{c}0.025 \\
(0.017)\end{array}$ & $\begin{array}{l}0.055^{* *} \\
(0.023)\end{array}$ & $\begin{array}{c}0.002 \\
(0.023)\end{array}$ & $\begin{array}{c}0.024 \\
(0.025)\end{array}$ & $\begin{array}{c}0.050 \\
(0.032)\end{array}$ & $\begin{array}{l}0.097 * * * \\
(0.033)\end{array}$ & $\begin{array}{l}-0.002 \\
(0.020)\end{array}$ \\
\hline$\Delta$ Backward $* \Delta$ Manager's time & $\begin{array}{l}-0.547 \\
(0.489)\end{array}$ & $\begin{array}{l}-0.239 \\
(0.682)\end{array}$ & $\begin{array}{l}-1.525^{*} \\
(0.789)\end{array}$ & $\begin{array}{l}-0.837 \\
(1.029)\end{array}$ & $\begin{array}{l}-0.623 \\
(0.880)\end{array}$ & $\begin{array}{l}-1.875^{*} \\
(1.016)\end{array}$ & $\begin{array}{c}0.240 \\
(0.635)\end{array}$ \\
\hline$\Delta$ Forward $* \Delta$ Manager's time & $\begin{array}{c}0.415 \\
(0.444)\end{array}$ & $\begin{array}{c}0.592 \\
(0.512)\end{array}$ & $\begin{array}{c}0.627 \\
(0.736)\end{array}$ & $\begin{array}{l}-0.896 \\
(0.978)\end{array}$ & $\begin{array}{l}1.480 \\
(1.201)\end{array}$ & $\begin{array}{c}1.945 \\
(1.192)\end{array}$ & $\begin{array}{c}0.144 \\
(0.490)\end{array}$ \\
\hline$\Delta$ Horizontal $* \Delta$ Manager's time & $\begin{array}{c}0.132 \\
(0.299)\end{array}$ & $\begin{array}{l}0.632 * * \\
(0.307)\end{array}$ & $\begin{array}{l}-0.270 \\
(0.395)\end{array}$ & $\begin{array}{c}0.143 \\
(0.426)\end{array}$ & $\begin{array}{c}0.003 \\
(0.599)\end{array}$ & $\begin{array}{l}0.814 * * \\
(0.388)\end{array}$ & $\begin{array}{l}-0.149 \\
(0.356)\end{array}$ \\
\hline$\Delta$ Manager's time & $\begin{array}{c}0.014 \\
(0.065)\end{array}$ & $\begin{array}{c}0.057 \\
(0.096)\end{array}$ & $\begin{array}{l}-0.035 \\
(0.089)\end{array}$ & $\begin{array}{l}0.245^{* *} \\
(0.123)\end{array}$ & $\begin{array}{l}-0.139 \\
(0.096)\end{array}$ & $\begin{array}{c}0.011 \\
(0.131)\end{array}$ & $\begin{array}{c}0.031 \\
(0.075)\end{array}$ \\
\hline $\begin{array}{l}\text { Observations } \\
\text { R-squared }\end{array}$ & $\begin{array}{c}4981 \\
0.60\end{array}$ & $\begin{array}{l}1714 \\
0.62\end{array}$ & $\begin{array}{c}3267 \\
0.60\end{array}$ & $\begin{array}{l}1975 \\
0.65\end{array}$ & $\begin{array}{r}2293 \\
0.57\end{array}$ & $\begin{array}{l}1264 \\
0.57\end{array}$ & $\begin{array}{l}3717 \\
0.62\end{array}$ \\
\hline \multicolumn{8}{|c|}{ Panel B: Firm Level Linkages } \\
\hline Sales to foreign firms (SalesFF) & $\begin{array}{l}0.036^{* *} \\
(0.016)\end{array}$ & $\begin{array}{c}0.036^{*} \\
(0.020)\end{array}$ & $\begin{array}{c}0.034 \\
(0.026)\end{array}$ & $\begin{array}{c}0.037 \\
(0.026)\end{array}$ & $\begin{array}{c}0.027 \\
(0.027)\end{array}$ & $\begin{array}{c}0.038 \\
(0.025)\end{array}$ & $\begin{array}{c}0.036^{*} \\
(0.020)\end{array}$ \\
\hline Exports & $\begin{array}{l}0.061 * * * \\
(0.018)\end{array}$ & $\begin{array}{c}0.035 \\
(0.024)\end{array}$ & $\begin{array}{c}0.041 \\
(0.029)\end{array}$ & $\begin{array}{l}0.059 * * * \\
(0.022)\end{array}$ & $\begin{array}{l}0.069 * * \\
(0.030)\end{array}$ & $\begin{array}{l}0.083 * * \\
(0.033)\end{array}$ & $\begin{array}{l}0.048^{* *} \\
(0.022)\end{array}$ \\
\hline Imports & $\begin{array}{l}-0.009 \\
(0.010)\end{array}$ & $\begin{array}{c}0.018 \\
(0.017)\end{array}$ & $\begin{array}{l}-0.017 \\
(0.012)\end{array}$ & $\begin{array}{c}0.000 \\
(0.016)\end{array}$ & $\begin{array}{l}-0.016 \\
(0.014)\end{array}$ & $\begin{array}{c}0.003 \\
(0.020)\end{array}$ & $\begin{array}{l}-0.009 \\
(0.011)\end{array}$ \\
\hline SalesFF $* \Delta$ Manager's time & $\begin{array}{l}-0.322 \\
(0.249)\end{array}$ & $\begin{array}{l}-0.426^{*} \\
(0.251)\end{array}$ & $\begin{array}{l}-0.192 \\
(0.509)\end{array}$ & $\begin{array}{c}0.007 \\
(0.453)\end{array}$ & $\begin{array}{l}-0.771^{*} \\
(0.453)\end{array}$ & $\begin{array}{l}-0.664 \\
(0.448)\end{array}$ & $\begin{array}{l}-0.116 \\
(0.293)\end{array}$ \\
\hline Exports $* \Delta$ Manager's time & $\begin{array}{c}0.117 \\
(0.255)\end{array}$ & $\begin{array}{c}0.042 \\
(0.301)\end{array}$ & $\begin{array}{l}-0.436 \\
(0.476)\end{array}$ & $\begin{array}{l}-0.100 \\
(0.332)\end{array}$ & $\begin{array}{l}-0.239 \\
(0.495)\end{array}$ & $\begin{array}{c}0.281 \\
(0.440)\end{array}$ & $\begin{array}{l}-0.062 \\
(0.297)\end{array}$ \\
\hline Imports $* \Delta$ Manager's time & $\begin{array}{l}-0.005 \\
(0.152)\end{array}$ & $\begin{array}{c}0.124 \\
(0.254)\end{array}$ & $\begin{array}{l}-0.012 \\
(0.195)\end{array}$ & $\begin{array}{c}0.361 \\
(0.259)\end{array}$ & $\begin{array}{l}-0.259 \\
(0.203)\end{array}$ & $\begin{array}{c}0.300 \\
(0.323)\end{array}$ & $\begin{array}{l}-0.032 \\
(0.171)\end{array}$ \\
\hline$\Delta$ Manager's time & $\begin{array}{c}0.021 \\
(0.079)\end{array}$ & $\begin{array}{c}0.068 \\
(0.112)\end{array}$ & $\begin{array}{l}-0.019 \\
(0.113)\end{array}$ & $\begin{array}{c}0.053 \\
(0.159)\end{array}$ & $\begin{array}{l}-0.013 \\
(0.115)\end{array}$ & $\begin{array}{l}-0.009 \\
(0.149)\end{array}$ & $\begin{array}{c}0.056 \\
(0.094)\end{array}$ \\
\hline Observations & 4981 & 1714 & 3267 & 1975 & 2293 & 1264 & 3717 \\
\hline R-squared & 0.60 & 0.61 & 0.60 & 0.65 & 0.57 & 0.57 & 0.62 \\
\hline
\end{tabular}

Note: The table reports the estimated spillover effects on revenue efficiency using the specification in equation (8) in the paper. Bureaucratic pressure is measured as the share of management's time spent on dealing with officials. To reduce noise, we use the average value of manager's time spent with officials in a given industry and country. Robust clustered standard errors in parentheses; $*$ significant at $10 \% ; * *$ significant at $5 \%$; *** significant at $1 \%$. 
Table 5: Effect of Whole/Partial Foreign Ownership and Source of FDI on Spillovers

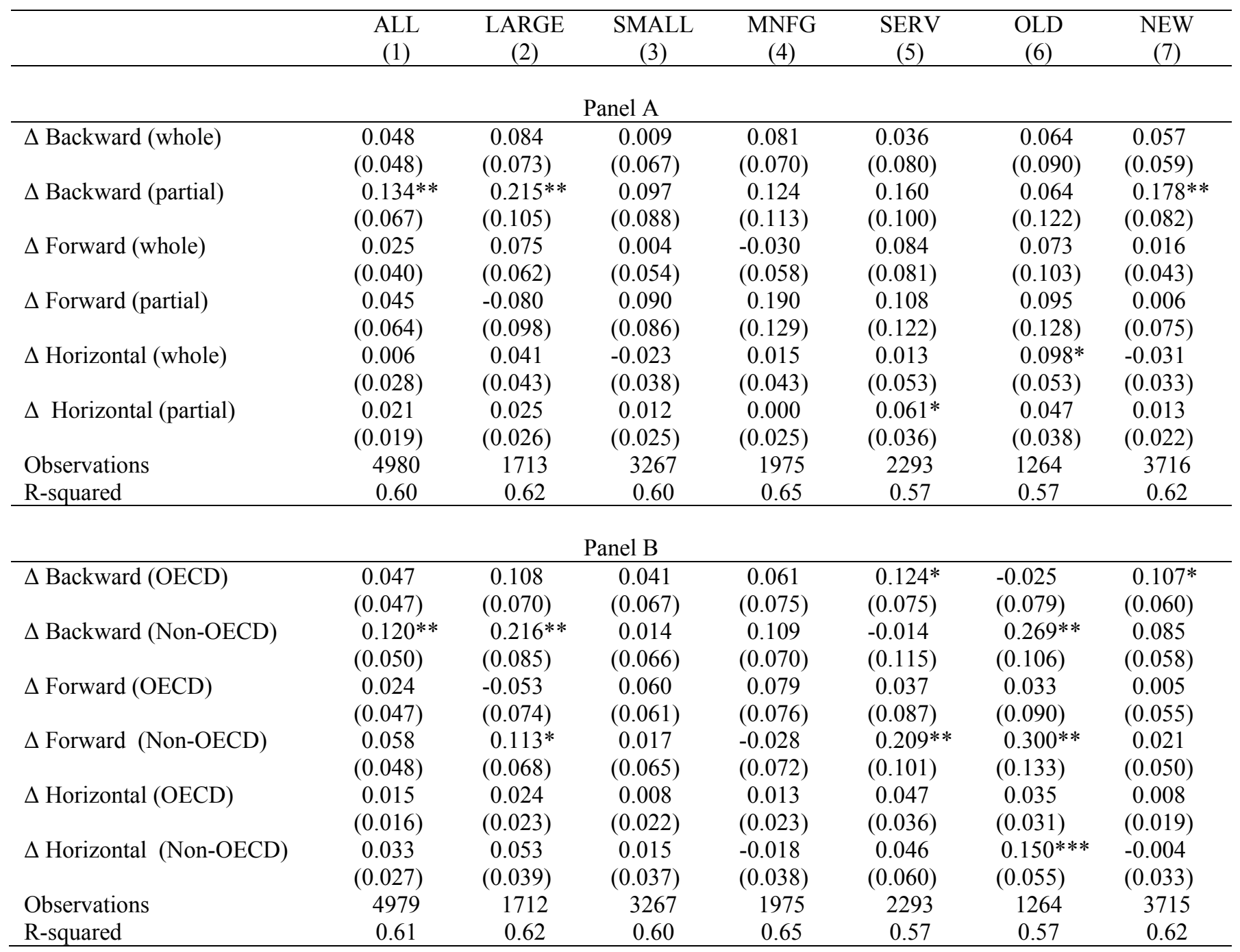

Note: The table reports estimated effects on revenue efficiency using a Cobb-Douglas production function, where the dependent variable is the growth rate of sales revenues; the independent variables include three inputs (utilization adjusted capital, the number of employees, materials), country and industry fixed effects, and the reported variables. The set of other controls is identical to the set used in Table 1. Panel A: The variables measuring changes in forward, backward and horizontal linkages are recalculated to differentiate the share of output in industry $j$ produced by wholly-owned v. partially-owned foreign firms. Panel B: The variables measuring changes in forward, backward and horizontal linkages have been recalculated to differentiate the share of output in industry $j$ produced by foreign firms with an OECD origin $\mathrm{v}$. foreign firms with a non-OECD origin. Robust clustered standard errors in parentheses; * significant at $10 \%$; ** significant at $5 \% ; * * *$ significant at $1 \%$. 
Table 6. Effect of Distance from the Frontier on the Strength of Spillovers

\begin{tabular}{|c|c|c|c|c|c|c|c|}
\hline & $\begin{array}{l}\text { ALL } \\
(1)\end{array}$ & $\begin{array}{l}\text { LARGE } \\
(2)\end{array}$ & $\begin{array}{l}\text { SMALL } \\
\text { (3) }\end{array}$ & $\begin{array}{c}\text { MNFG } \\
(4)\end{array}$ & $\begin{array}{c}\text { SERV } \\
(5)\end{array}$ & $\begin{array}{l}\text { OLD } \\
(6)\end{array}$ & $\begin{array}{c}\text { NEW } \\
(7)\end{array}$ \\
\hline \multicolumn{8}{|c|}{ Panel A } \\
\hline$\Delta$ Backward & $\begin{array}{c}0.205^{*} \\
(0.124)\end{array}$ & $\begin{array}{c}0.260 \\
(0.183)\end{array}$ & $\begin{array}{c}0.171 \\
(0.174)\end{array}$ & $\begin{array}{c}0.212 \\
(0.158)\end{array}$ & $\begin{array}{c}0.153 \\
(0.261)\end{array}$ & $\begin{array}{l}0.477^{* *} \\
(0.236)\end{array}$ & $\begin{array}{c}0.086 \\
(0.145)\end{array}$ \\
\hline$\Delta$ Forward & $\begin{array}{c}0.004 \\
(0.114)\end{array}$ & $\begin{array}{c}0.089 \\
(0.166)\end{array}$ & $\begin{array}{l}-0.109 \\
(0.157)\end{array}$ & $\begin{array}{c}0.005 \\
(0.163)\end{array}$ & $\begin{array}{c}0.004 \\
(0.257)\end{array}$ & $\begin{array}{c}0.025 \\
(0.225)\end{array}$ & $\begin{array}{l}-0.032 \\
(0.130)\end{array}$ \\
\hline$\Delta$ Horizontal & $\begin{array}{c}0.056 \\
(0.050)\end{array}$ & $\begin{array}{c}0.017 \\
(0.064)\end{array}$ & $\begin{array}{c}0.068 \\
(0.077)\end{array}$ & $\begin{array}{c}0.123^{*} \\
(0.067)\end{array}$ & $\begin{array}{c}0.141 \\
(0.108)\end{array}$ & $\begin{array}{c}0.130 \\
(0.097)\end{array}$ & $\begin{array}{c}0.015 \\
(0.059)\end{array}$ \\
\hline$\Delta$ Backward $*$ Distance & $\begin{array}{l}-0.043 \\
(0.041)\end{array}$ & $\begin{array}{l}-0.040 \\
(0.059)\end{array}$ & $\begin{array}{l}-0.043 \\
(0.059)\end{array}$ & $\begin{array}{l}-0.041 \\
(0.056)\end{array}$ & $\begin{array}{l}-0.024 \\
(0.081)\end{array}$ & $\begin{array}{l}-0.142 * \\
(0.074)\end{array}$ & $\begin{array}{c}0.006 \\
(0.050)\end{array}$ \\
\hline$\Delta$ Forward $*$ Distance & $\begin{array}{c}0.009 \\
(0.038)\end{array}$ & $\begin{array}{l}-0.027 \\
(0.056)\end{array}$ & $\begin{array}{c}0.049 \\
(0.052)\end{array}$ & $\begin{array}{c}0.008 \\
(0.057)\end{array}$ & $\begin{array}{c}0.023 \\
(0.082)\end{array}$ & $\begin{array}{c}0.016 \\
(0.072)\end{array}$ & $\begin{array}{c}0.017 \\
(0.045)\end{array}$ \\
\hline$\Delta$ Horizontal $*$ Distance & $\begin{array}{l}-0.017 \\
(0.018)\end{array}$ & $\begin{array}{l}-0.001 \\
(0.021)\end{array}$ & $\begin{array}{l}-0.023 \\
(0.027)\end{array}$ & $\begin{array}{l}-0.046^{*} \\
(0.024)\end{array}$ & $\begin{array}{l}-0.036 \\
(0.039)\end{array}$ & $\begin{array}{l}-0.033 \\
(0.034)\end{array}$ & $\begin{array}{l}-0.006 \\
(0.021)\end{array}$ \\
\hline Distance & $\begin{array}{l}-0.011 * * * \\
(0.004)\end{array}$ & $\begin{array}{l}-0.008 \\
(0.006)\end{array}$ & $\begin{array}{l}-0.010 * \\
(0.005)\end{array}$ & $\begin{array}{l}-0.011^{*} \\
(0.006)\end{array}$ & $\begin{array}{l}-0.019 * * * \\
(0.006)\end{array}$ & $\begin{array}{l}-0.008 \\
(0.008)\end{array}$ & $\begin{array}{l}-0.010^{* *} \\
(0.005)\end{array}$ \\
\hline $\begin{array}{l}\text { Observations } \\
\text { R-squared }\end{array}$ & $\begin{array}{r}4867 \\
0.61 \\
\end{array}$ & $\begin{array}{l}1655 \\
0.62 \\
\end{array}$ & $\begin{array}{r}3212 \\
0.60 \\
\end{array}$ & $\begin{array}{l}1939 \\
0.65 \\
\end{array}$ & $\begin{array}{c}2230 \\
0.58\end{array}$ & $\begin{array}{l}1235 \\
0.58 \\
\end{array}$ & $\begin{array}{l}3632 \\
0.62 \\
\end{array}$ \\
\hline \multicolumn{8}{|c|}{ Panel B: Firm Level Linkages } \\
\hline Sales to foreign firms (SalesFF) & $\begin{array}{c}0.050 \\
(0.036)\end{array}$ & $\begin{array}{c}0.014 \\
(0.046)\end{array}$ & $\begin{array}{c}0.091 \\
(0.063)\end{array}$ & $\begin{array}{l}0.117^{* *} \\
(0.058)\end{array}$ & $\begin{array}{l}-0.037 \\
(0.074)\end{array}$ & $\begin{array}{c}0.088 \\
(0.083)\end{array}$ & $\begin{array}{c}0.021 \\
(0.041)\end{array}$ \\
\hline Exports & $\begin{array}{c}0.055 \\
(0.036)\end{array}$ & $\begin{array}{c}0.024 \\
(0.047)\end{array}$ & $\begin{array}{c}0.118^{*} \\
(0.063)\end{array}$ & $\begin{array}{c}0.059 \\
(0.042)\end{array}$ & $\begin{array}{c}0.111 \\
(0.123)\end{array}$ & $\begin{array}{c}0.019 \\
(0.071)\end{array}$ & $\begin{array}{c}0.077^{*} \\
(0.044)\end{array}$ \\
\hline Imports & $\begin{array}{l}-0.002 \\
(0.024)\end{array}$ & $\begin{array}{l}-0.017 \\
(0.040)\end{array}$ & $\begin{array}{c}0.016 \\
(0.030)\end{array}$ & $\begin{array}{l}-0.015 \\
(0.035)\end{array}$ & $\begin{array}{l}-0.007 \\
(0.037)\end{array}$ & $\begin{array}{l}-0.016 \\
(0.057)\end{array}$ & $\begin{array}{c}0.003 \\
(0.026)\end{array}$ \\
\hline$\Delta$ SalesFF $*$ Distance & $\begin{array}{l}-0.000 \\
(0.014)\end{array}$ & $\begin{array}{c}0.017 \\
(0.017)\end{array}$ & $\begin{array}{l}-0.018 \\
(0.026)\end{array}$ & $\begin{array}{l}-0.033 \\
(0.028)\end{array}$ & $\begin{array}{c}0.032 \\
(0.024)\end{array}$ & $\begin{array}{l}-0.011 \\
(0.030)\end{array}$ & $\begin{array}{c}0.008 \\
(0.017)\end{array}$ \\
\hline$\Delta$ Exports $*$ Distance & $\begin{array}{l}-0.002 \\
(0.014)\end{array}$ & $\begin{array}{c}0.003 \\
(0.019)\end{array}$ & $\begin{array}{l}-0.028 \\
(0.023)\end{array}$ & $\begin{array}{l}-0.003 \\
(0.019)\end{array}$ & $\begin{array}{l}-0.013 \\
(0.041)\end{array}$ & $\begin{array}{c}0.021 \\
(0.025)\end{array}$ & $\begin{array}{l}-0.015 \\
(0.018)\end{array}$ \\
\hline$\Delta$ Imports * Distance & $\begin{array}{l}-0.004 \\
(0.009)\end{array}$ & $\begin{array}{c}0.010 \\
(0.015)\end{array}$ & $\begin{array}{l}-0.013 \\
(0.011)\end{array}$ & $\begin{array}{c}0.001 \\
(0.014)\end{array}$ & $\begin{array}{l}-0.003 \\
(0.013)\end{array}$ & $\begin{array}{c}0.001 \\
(0.020)\end{array}$ & $\begin{array}{l}-0.005 \\
(0.010)\end{array}$ \\
\hline Distance & $\begin{array}{l}-0.008^{*} \\
(0.005)\end{array}$ & $\begin{array}{l}-0.011 \\
(0.008)\end{array}$ & $\begin{array}{l}-0.003 \\
(0.006)\end{array}$ & $\begin{array}{l}-0.004 \\
(0.007)\end{array}$ & $\begin{array}{l}-0.019 * * \\
(0.008)\end{array}$ & $\begin{array}{l}-0.008 \\
(0.010)\end{array}$ & $\begin{array}{l}-0.009 \\
(0.005)\end{array}$ \\
\hline Observations & 4867 & 1655 & 3212 & 1939 & 2230 & 1235 & 3632 \\
\hline R-squared & 0.61 & 0.62 & 0.60 & 0.65 & 0.58 & 0.57 & 0.62 \\
\hline
\end{tabular}

Note: The table reports estimated spillover effects on revenue efficiency using the specification in equation (8) in the paper. Distance is measured according to the Mahalanobis metric using all foreign firms. See text for further details on the construction of this metric. Robust clustered standard errors in parentheses; $*$ significant at $10 \%$; * significant at 5\%; *** significant at $1 \%$. 